\title{
Energy and Water Related Parameters in Tomato and Cucumber Greenhouse Crops in Semiarid Mediterranean Regions. A Review, Part I: Increasing Energy Efficiency
}

\author{
Georgios Nikolaou 1,*(D), Damianos Neocleous ${ }^{2}$ (D), Anastasis Christou 2 (D), Polycarpos Polycarpou ${ }^{2}$, \\ Evangelini Kitta ${ }^{1}$ and Nikolaos Katsoulas ${ }^{1, * \mathbb{D}}$
}

1 Laboratory of Agricultural Constructions and Environmental Control, Department of Agriculture Crop Production and Rural Environment, School of Agricultural Sciences, University of Thessaly, Fytokou Str., 38446 Volos, Greece; evkitta@uth.gr

2 Department of Natural Resources and Environment, Agricultural Research Institute, 1516 Nicosia, Cyprus; d.neocleous@ari.gov.cy (D.N.); anastasis.christou@ari.gov.cy (A.C.); p.polycarpou@arinet.ari.gov.cy (P.P.)

* Correspondence: gnicolaounic@gmail.com (G.N.); nkatsoul@uth.gr (N.K.); Tel.: +30-24210-93249 (G.N. \& N.K.)

\section{check for} updates

Citation: Nikolaou, G.; Neocleous, D.; Christou, A.; Polycarpou, P.; Kitta, E.; Katsoulas, N. Energy and Water Related Parameters in Tomato and Cucumber Greenhouse Crops in Semiarid Mediterranean Regions. A Review, Part I: Increasing Energy Efficiency. Horticulturae 2021, 7, 521. https://doi.org/10.3390/

horticulturae7120521

Academic Editor: Hye-Ji Kim

Received: 29 October 2021

Accepted: 23 November 2021

Published: 25 November 2021

Publisher's Note: MDPI stays neutral with regard to jurisdictional claims in published maps and institutional affiliations.

Copyright: (c) 2021 by the authors. Licensee MDPI, Basel, Switzerland. This article is an open access article distributed under the terms and conditions of the Creative Commons Attribution (CC BY) license (https:// creativecommons.org/licenses/by/ $4.0 /)$.

\begin{abstract}
Countries located in the Mediterranean region share many common features in terms of agricultural sustainability and economic realities of modern farming, as they are affected by water scarcity, energy use and climate suitability. Greenhouses are considered as a mitigation measure to combat climate change and as a sustainable production system. The majority of greenhouses in the Mediterranean region are rudimentary, while those in Central and North Europe are characterized by equipment of a high technological level for greenhouse climate and fertigation management. However, the technological innovations and research originating from Central and North Europe glasshouses may not be appropriate for use in Mediterranean plastic greenhouses when considering the trade-off between agronomic needs and potential energy savings. Identifying energy measures suitable for the local climate will improve energy efficiency and crop performance toward the goal of greenhouse sustainability. This review mainly focuses on renewable and energy-efficient control systems in Mediterranean greenhouses, where crops such as tomato and cucumber are widely grown.
\end{abstract}

Keywords: climograph; carbon dioxide; photovoltaic system; solar energy; vapor pressure deficit; renewable energy sources

\section{Introduction}

Greenhouses and high tunnels are estimated to account for approximately 700,000 ha worldwide, mainly concentrated in Asia and Europe [1-3]. About 260,000 ha of greenhouse structures covered with plastic film (i.e., low-density polyethylene) are consolidated in the Mediterranean region. They are mainly located in Spain, southern France, Italy, Greece and from Turkey to Morocco [4-7]. Only 9\% are covered with glass, i.e., less than 5\% in Greece, Israel and Jordan; 12\% in Turkey; 16\% in Morocco; and 25\% in Egypt [8]. During the last decade, the economic growth of many developing countries (e.g., Morocco) has been based mainly on the production of warm season vegetables such as cucumber (Cucumis sativus L.) and tomato (Solanum lycopersicum L.) under low-cost solar-passive greenhouses (i.e., unheated greenhouses) for an extended harvesting season $[9,10]$.

Greenhouses, compared to open fields, have intensified agriculture by extending the growing season and producing more per square meter of cultivated land. However, as yearly production is more energy intensive, the substantial growth has led to a large increase in energy demand [7,8]. Due to their lightweight construction and inefficient insulation, greenhouses are considered one of the most energy-intensive sectors of the agricultural industry, as they consume more fossil energy to operate compared to other 
buildings of similar size [11]. They are about 10 times less energy efficient than animal production and 100 times less than grain production and mixed agriculture [12].

A serious weakness of Mediterranean greenhouses is the large amount of energy required to maintain optimal environmental conditions for crop growth [3], which limits the operation period to about 9 months due to very high summer temperatures. Heating, is adopted in some cases to achieve earlier production during the winter-spring growing season. However, several actions should be taken to match the competitiveness from open-field cucumber and tomato production during the summer-autumn growing period. Since the majority of greenhouses are of low-to-medium technology, suboptimal growing conditions are usually associated with inefficient climate and energy control and high emissions of chemicals to the environment which, in turn, increases the production cost and environmental consequences. Thus, the major challenge in Mediterranean greenhouses is to find ways to improve yield per drop of water and unit of energy. Increased investment is required and needs to be considered in terms of return on investments [13]. In any case, reduction in the energy requirement is related to the strategic choices of the growers in relation to the structure of the greenhouse and climate control equipment used, such as ventilation systems, cooling and heating and cultivation practices. For example, Villarreal-Guerrero et al. [14] suggested that maintaining high transpiration (higher leaf area index) during summer is an efficient method for cooling a greenhouse, as the majority of the water absorbed by the plant can be returned as vapor to the greenhouse air and cool the environment. In another case, Kittas et al. [13] suggested that maintaining low transpiration rates during winter can have positive effects on the energy efficiency of the greenhouse, as less water is released into the greenhouse air and less energy is required for humidity control. In any case, when making decisions, better management of farming activities should be focused on optimizing the number of outputs with the same number of inputs [15]. Indeed, for several countries within the EU (such as Spain, Italy and Greece), the water policy has been driven to a large extend by the EU legislation, which provides the framework for comprehensively addressing water protection and for achieving good status for inland surface waters, coastal waters and groundwater. Various management plans were developed and adopted in order to strengthen aquatic ecosystems and promote the resilience of the environment to climate change, therefore managing inputs (i.e., water and fertilizers) in a more acceptable manner.

Recently, researchers have shown an increased interest in the adaptation of green energy technologies in greenhouses, and this work (part I) offers some important insights into the use of renewable energy systems for sustainability in Mediterranean greenhouse cultivation to increase energy efficiency. Recognizing the critical role of water, part II of the review article draws the reader's attention to the challenges that greenhouse growers in arid and semi-arid areas in the Mediterranean face in relation to water and nutrient supply for tomato and cucumber crops. Thus, parts I and II will focus on the trade of natural resources (i.e., energy and water), which is needed during the production process, as it "saves" the importing country from allocating their own natural resources [16]. Indeed, energy and $\mathrm{CO}_{2}$ footprint emissions constitute a global concern, as local contributions from even the least developing countries have an effect. In this light, setting the goal of a climate-neutral economy is a strategic choice of each country to achieve environmental goals for the benefit of society and to ensure a sustainable future for all.

\section{Greenhouse Environment}

2.1. Energy Conditions

\subsubsection{Climate}

One of the most important factors, which plays a fundamental role in greenhouse energy requirements, is climate control (e.g., control of air temperature, relative humidity and light). Under Mediterranean climatic conditions, greenhouse optimal climate control requires the operation of heating, ventilation and cooling systems accounting for $70-85 \%$ of the total yearly greenhouse operating costs $[17,18]$. Thus, the challenge is to increase 
energy efficiency (i.e., product yield per unit of energy) in Mediterranean greenhouses in a sustainable manner under recent environmental challenges $[19,20]$. This can be achieved through the introduction of novel technologies as well as the incorporation of renewable energy sources and the development of smart energy management algorithms. For example, from climograph (i.e., a graphical representation of monthly averages of solar radiation and air temperature, Figure 1), it can be concluded that in northern European countries, the greenhouse climate can be effectively controlled throughout the year only by the operation of heating and the intermittent operation of ventilation systems. Under Mediterranean climatic conditions, greenhouse improvements require the year-round operation of heating, ventilation and cooling systems.

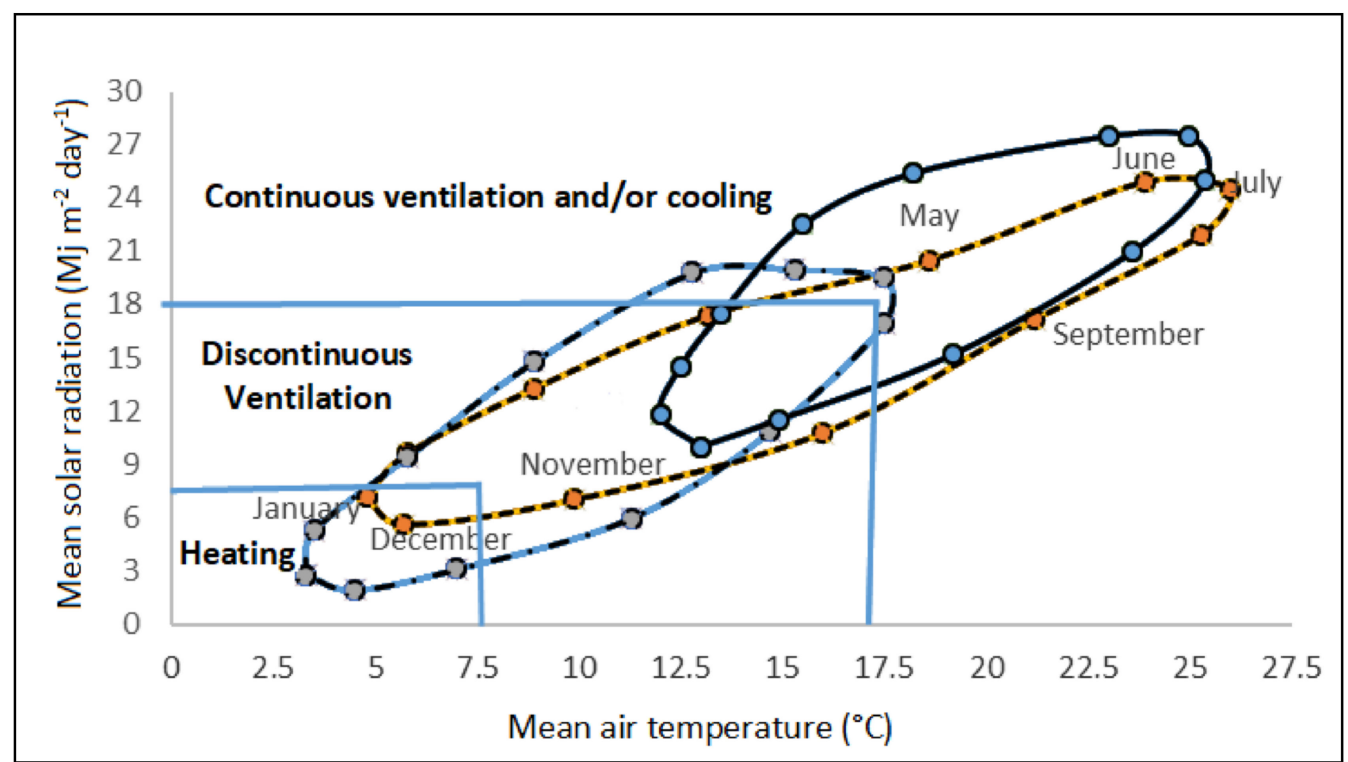

Figure 1. Greenhouse micro-climatic improvements needed in different locations; solid line, greenhouse in an inland Mediterranean climate (e.g., Larisa, Greece, $39^{\circ} 38^{\prime} 36.4272^{\prime \prime} \mathrm{N}$ and $22^{\circ} 24^{\prime} 47.55^{\prime \prime} \mathrm{E}$ ); round dot, greenhouse in a coastal Mediterranean climate (e.g., Almeria, Spain, 36 50'17.3004" $\mathrm{N}$ and $2^{\circ} 27^{\prime} 35.0640^{\prime \prime} \mathrm{W}$ ); dash dot, greenhouse in a northern European climate (e.g., Amsterdam, Netherlands, $52^{\circ} 22^{\prime} 40.6416^{\prime \prime} \mathrm{N}$ and $4^{\circ} 53^{\prime} 49.4520^{\prime \prime}$ E.).

On the other hand, in semi-arid eastern Mediterranean countries, as in the case of Cyprus, although heating is only needed from November to April, the heating energy requirements are twice that required for all other processes demanding energy in the greenhouse throughout the year [21]. This means that an annual heating energy demand of $850 \mathrm{MJ} \mathrm{m}^{-2}$ is required for a Mediterranean tomato crop, resulting in a heating cost between 3.5-15 EUR $\mathrm{m}^{-2}$ depending on the greenhouse type [13]. On the contrary, energy consumption in a greenhouse without any heating equipment is drastically lower (i.e., $80 \%$ decrease) and is estimated at $170 \mathrm{MJ} \mathrm{m}^{-2}$ [21].

The daily operation hours of several greenhouse equipment in Cyprus is presented in Table 1. For a heating system, the maximum daily operation is estimated at $6 \mathrm{~h}$ in January, whereas an active cooling system requires 20 operation hours in August. The role of crop genotypes on annual energy use is presented in Table 2. When assessing the energy performance of individual crops in Turkey, the annual energy demand for heating a cucumber crop was twofold higher than that of tomato, while the annual cost of cooling was about 33\% less [22]. Meanwhile, irrigation cost comes third in primary energy consumption. Indeed, the amount of energy required for groundwater extracting for irrigation in Cyprus was estimated to be as high as EUR 1.94 per hour operation for a typical flow rate of $8 \mathrm{~m}^{-3} \mathrm{~h}^{-1}$ and a total dynamic head of $300 \mathrm{~m}$ (unpublished data, Cyprus Department of Agriculture). Furthermore, it is estimated that the electrical energy requirements for a forced air ventilation system is about $100,000 \mathrm{kWh}$ per greenhouse ha [13]. 
Table 1. Estimated daily hours of operations for several equipment in a $2000 \mathrm{~m}^{2}$ coastal greenhouse at various months of the year [21].

\begin{tabular}{ccccccccccccc}
\hline Equipment & $\mathbf{J}$ & $\mathbf{F}$ & $\mathbf{M}$ & $\mathbf{A}$ & $\mathbf{M}$ & $\mathbf{J}$ & $\mathbf{J}$ & $\mathbf{A}$ & $\mathbf{S}$ & $\mathbf{O}$ & $\mathbf{N}$ & $\mathbf{D}$ \\
\hline Heating & 6 & 5 & 3 & 1 & 0 & 0 & 0 & 0 & 0 & 0 & 2 & 4 \\
Cooling & 0 & 0 & 3 & 6 & 8 & 10 & 14 & 20 & 18 & 9 & 0 & 0 \\
Cooling panel pumps & 0 & 0 & 2 & 5 & 7 & 10 & 13 & 18 & 16 & 8 & 0 & 0 \\
Irrigation pumps & 2 & 2 & 2 & 2 & 4 & 4 & 4 & 4 & 3 & 2 & 2 & 2 \\
Circulation fans & 6 & 5 & 3 & 1 & 2 & 2 & 2 & 2 & 2 & 2 & 2 & 4 \\
Windows motor & 0.05 & 0.05 & 0.05 & 0.05 & 0.05 & 0.05 & 0.05 & 0.05 & 0.05 & 0.05 & 0.05 & 0.05 \\
Thermal screen motor & 0.08 & 0.08 & 0.08 & 0.08 & 0.08 & 0.08 & 0.08 & 0.08 & 0.08 & 0.08 & 0.08 & 0.08 \\
\hline
\end{tabular}

Table 2. Monthly energy variation (electricity in $\mathrm{kWh}$ ) demand for cucumber and tomato in a $150 \mathrm{~m}^{2}$ greenhouse [22].

\begin{tabular}{cccccccccccccc}
\hline Crops & J & F & M & A & M & J & J & A & S & O & N & D & Total \\
\hline Cucumber heating & 2281 & 2040 & 1632 & 1037 & 0 & 0 & 0 & 0 & 0 & 798 & 1678 & 2439 & 11,905 \\
Tomato heating & 1213 & 1110 & 779 & 352 & 0 & 0 & 0 & 0 & 0 & 190 & 791 & 1294 & 5729 \\
Cucumber cooling & 0 & 0 & 0 & 0 & 3087 & 4087 & 0 & 0 & 4374 & 0 & 0 & 0 & 11,548 \\
Tomato cooling & 0 & 0 & 0 & 0 & 4309 & 5481 & 0 & 0 & 5612 & 0 & 0 & 0 & 15,402 \\
\hline
\end{tabular}

\subsubsection{Renewable Energy}

To improve the greenhouse energy efficiency in Mediterranean greenhouses, measures should be taken by farmers to reduce energy losses and consumption of heating oil. One such measure is the replacement of heating oil with gas (e.g., natural gas, biogas) or with renewable energy sources, such as aerothermal, solar, biomass, or geothermal energy. However, the heat pumps that use hydrothermal, geothermal or aerothermal heat applications have higher requirements in regard to temperature, electrical or other auxiliary energy. Therefore, the energy used to operate the heat pumps should be subtracted from the useful thermal energy they provide. In this content, the Directive 2009/28/EC [23] of the European Parliament and Council on the promotion of renewable energy use takes into account only heat pumps that provide a significantly higher percentage of heat energy than that consumed for their operation. It seems that the most economical type is the air-to-water pump due to the lower initial installation cost [24]. In such a type of heat pump, the heat is pumped from the atmospheric air and does not require costly drilling as in the case of geothermal pumps. However, during the heating period, its efficiency varies according to the required temperature in the greenhouse and to that of the outside. In the case of geothermal heat pumps, the cost increases due to the high cost of drilling required to install heat exchangers in soil. Alternatively, by exploiting shallow geothermal energy, greenhouses can be heated by taking advantage of the constant soil temperature [25]. Shallow geothermal energy is the energy stored in the form of heat of the earth's crust, at depths up to $200 \mathrm{~m}$ and with subsoil temperatures up to $18^{\circ} \mathrm{C}$. This energy comes from the absorption of solar radiation (almost $50 \%$ of the total amount that reaches the earth) from the earth's surface. Throughout the year, in the latitudes of the temperate zone, it remains approximately constant below some depth at $22{ }^{\circ} \mathrm{C}$ (Figure 2). Regarding the cost of installation of these systems, a corresponding techno-economic study must be carried out in each case, taking into account the local market's economic environment (prices, labor). The heating system using shallow geothermal energy was tested for greenhouse vegetable production in two countries of the eastern Mediterranean region (i.e., Cyprus and Greece) (see adapt2change LIFE project, https:/ / www.adapt2change.org/en/home, accessed on 2 November 2021 [26]). The results indicated savings in the first-year energy consumption above $60 \%$ in a greenhouse using shallow geothermal energy for heating as compared to a greenhouse heated with heating oil. 


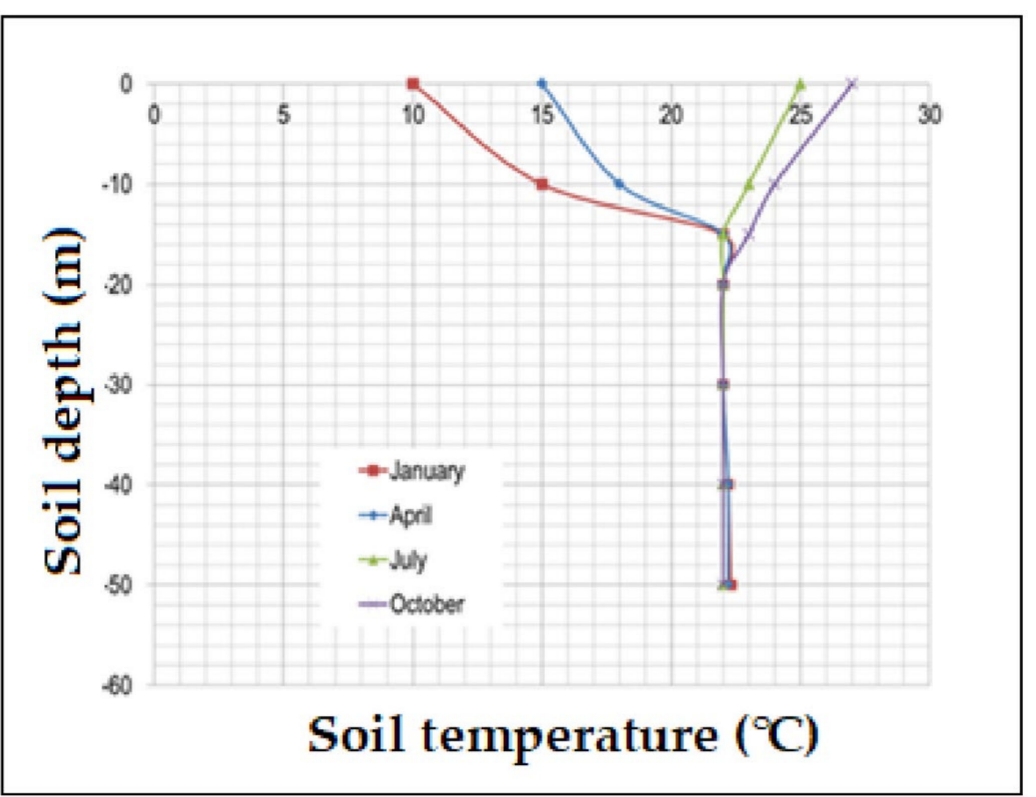

Figure 2. Characteristic temperature profile in soil over the period of a year (at Zygi, Cyprus).

One of the most important sources of renewable energy in Central Europe is wood biomass [19]. However, as there are limited forest resources available in the Mediterranean, it becomes evident that it is difficult to implement wood biomass in a cost-effective manner. In addition, the payback period of a biomass resource investment is estimated between 10 to 22 years when substituting heating oil systems and 18 to 22 years for replacing natural gas heating systems, which is not an encouraging factor for investment [18]. Other sources of biomass should be evaluated at the local level, such as sewage sludge and agricultural residues, considering the local fossil fuel price.

Despite the high solar thermal potential in the Mediterranean basin, (average $1687 \mathrm{kWh} \mathrm{y}^{-1}$ in Cyprus; [27]), the application of solar thermal systems in the Mediterranean region is also very scarce. The energy required for heating a greenhouse is mainly needed at night during winter months. Consequently, there is a complete mismatch between energy consumption and energy production. Large-scale thermal energy storage tanks are expensive, and their efficiency questionable; in addition, a large installation area is needed for solar collectors, which, in turn, changes agricultural land use [21]. In the case of southern Spain, Montero and Short [28] suggested that a ratio of solar collectors of 0.5 of the greenhouse cover area is needed to satisfy $80 \%$ of the heating requirements. In the case of Cyprus, however, Polycarpou [29] showed that, considering the large initial installation cost and the yearly energy savings from such a system, there is an optimum energy mix consisting of $90 \%$ solar energy and $10 \%$ heat provided by an auxiliary system of burning fossil fuel oil or biomass. This could be achieved by installing a solar collector area equal to $60 \%$ of the ground area of a greenhouse. For a viable system, a state subsidy of at least $55 \%$ of the initial cost is required. Recently, solar modules have been built on top of greenhouse structures as an alternative method of energy production by shading the greenhouse. However, crop-specific research is steel needed in order to determine the optimum percentage of panels that will not affect yield [30]. Ureña-Sánchez et al. [31] applied photovoltaic panels on top of a greenhouse with a $9.8 \%$ roof covering. They showed that no significant differences were observed in air temperature, relative humidity, productivity or quality of tomato crop between shaded and un-shaded treatments. In another study, no significant effects on plant growth were detected with photovoltaic panels on greenhouse roofs with a coverage less than $50 \%$ based on a checkerboard configuration arrangement [32]. The same author suggested that photovoltaic panels can also act as shading elements to mitigate overheating of the greenhouse if implemented as automatic, internal, movable screens. Furtermore, Ezzaeri et al. [33] used photovoltaic panels with a coverage of $40 \%$ of a roof 
in a canary-type greenhouse in the Atlantic coast of Morocco in order to protect tomato crops from solar radiation during the intense summer. However, in winter, the use of photovoltaic panels resulted in a delay in tomato maturity.

Wind energy's potential is predicted to play an important role in supplying electrical energy to a greenhouse. However, the payback period, using local climatic data and prices in Cyprus estimated for a wind turbine system (Table 3), is higher than that of a photovoltaic system [23]. In the case of Almeria (Spain), Baeza et al. [34] estimated that about $10 \mathrm{~m}^{2}$ swept for a wind turbine per $\mathrm{m}^{2}$ of greenhouse is needed to cover the peak heat requirements in January at sunrise and $2.6 \mathrm{~m}^{2}$ at sunset. The authors suggested that the direct use of wind energy for cooling or heating greenhouses is not an economically viable option.

Table 3. Summary of results for a $50 \mathrm{~kW}$ wind turbine system [21].

\begin{tabular}{cc}
\hline Parameter & Value \\
\hline Initial investment & EUR 142,330 \\
Installed power & $50 \mathrm{~kW}^{-1}$ \\
Load energy consumption & $62 \mathrm{MWh} \mathrm{y}^{-1}$ \\
Energy delivered by photovoltaics & $55.38 \mathrm{MWh} \mathrm{y}^{-1}$ \\
Internal rate of return & $11.9 \%$ \\
Net present value & EUR 7792 \\
Payback period & 8 years \\
\hline
\end{tabular}

The replacement of fossil fuel with sustainable and renewable energy sources (Figure 3) is related to the reliability of the availability of the alternative source and its fluctuations in price, since investment costs are generally high. Hence, it is also critical to achieve the economy of scale by identifying locally the most suitable sustainable energy sources connected to a large greenhouse area. It is therefore recommended to use specialized advisory services and consultants when considering the use of these sustainable energy sources. In any case, growers who decide to use wind or a photovoltaic energy system normally have the option to sell energy directly to the grid line [19]. Data evaluation on the use of renewable and sustainable energy for greenhouse crops is well reported in the literature [35-38].

\subsubsection{Shading and Light Conditions}

The use of shading nets and whitewash (i.e., the application of a water solution with a calcium carbonate) is common practice in the modification of the indoor climate for crops such as tomato and cucumber during months of high radiation, as it allows for the intensity of light and, therefore, the energy needed for cooling to be reduced [39]. Indeed, as cited by Nikolaou et al. [40], there are reports of a reduction of up to $9{ }^{\circ} \mathrm{C}$ between internal and external greenhouse air temperatures in a whitewashed roof greenhouse combined with natural ventilation. However, there is a negative effect on photosynthesis during hours that radiation is not in excess (early morning or in the afternoon) when whitewash is applied instead of mobile shading. Nikolaou et al. [40] evaluated the effects of whitewash combined with a forced air ventilation system in a late autumn-summer coastal Mediterranean area. They concluded that there were no significant losses in cucumber yield despite a reduction in the greenhouse transmittance of global radiation by $45 \%$. In addition, higher water use efficiency was obtained in the whitewash treatment. Furthermore, Kitta and Katsoulas [41], in an inland Mediterranean climate, evaluated the effect of shading intensities of 35\% and $50 \%$ on cucumber growth. They concluded that photosynthesis and leaf area index were reduced almost linearly with the increasing percentage of shading. According to the same authors, shaded plants do not acclimate to shade conditions and respond directly to lighting conditions, which practically enhances the usefulness of periodic shading as a tool for improving the microclimate in greenhouses. In the same context, Klaring et al. [42] applied transparent screens as a method of reducing heating requirements in winter cucumber 
crops, concluding that every $1 \%$ reduction in photosynthetic active radiation (PAR) induces a reduction in the leaf area and photosynthesis by $0.40 \%$. Thus, the customization of the optical properties of greenhouse cover material is a subject of interest, where plastic films with modified light regimes interactively affect the indoor microclimate [7] and affect the photomorphogenesis of plants (see SPECTRAFOIL project, https:/ / cordis.europa.eu/ project/id/QLK5-CT-2001-70496; accessed on 20 November 2021, [43]). For example, antifog and infrared additives integrated into the plastics affect the transmission of infrared radiation inside the greenhouse [44], whereas UV (ultraviolet) blocking material affects the spread of aphids and whiteflies [45-48].

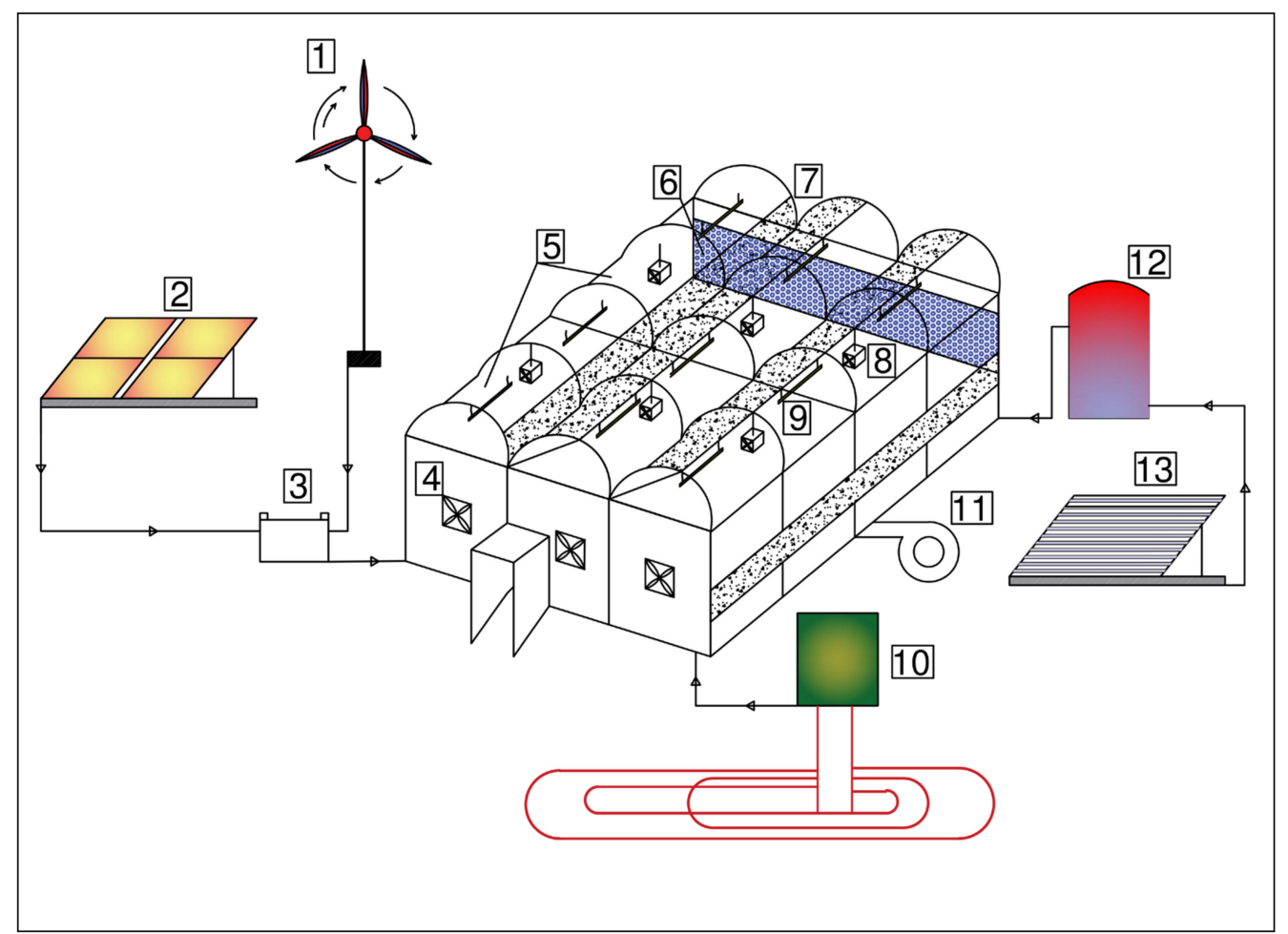

Figure 3. Technologies for energy and climate control in the greenhouse: 1 , wind turbine; 2 , photovoltaic panel; 3, battery bank and inverter; 4 , forced air ventilation system; 5 , photo selective greenhouse cover; 6, evaporative pad; 7 , natural air ventilation system; 8 , air circulation fans; 9, artificial lighting; 10 , ground source heat pump system; $11, \mathrm{CO}_{2}$ generator; 12 , heat storage unit, 13 , solar collector.

On the other hand, Palmitessa et al. [49] evaluated the effect of supplemental light in Mediterranean greenhouses. They showed that during periods with low levels of solar radiation, the yield of tomato was increased by $21.7 \%$ by using LEDs as supplemental lighting with a photoperiod of $18 \mathrm{~h}$. Lighting increased the greenhouse energy electrical demand from 118 (June) to 144 (January) $\mathrm{kWh}$ [22]. Therefore, it is essential to know how much of the crop productivity is affected in relation to light transmission reduction caused by the greenhouse structure or by cladding materials in the case of economic analysis of the various techniques, which may be used to improve the insulation of the greenhouse. Quantification of this relationship is also important when considering the application of supplemental lighting in Mediterranean greenhouses during the winter season [50]. For example, Abdel-Ghany et al. [4] suggested that NIR (near-infrared radiation)-reflecting plastic films are more suitable for regions of high solar radiation and short winter as they could reduce the internal air temperature by up to $5^{\circ} \mathrm{C}$. However, when the external air temperature exceeds $45^{\circ} \mathrm{C}$, an active cooling system is required. 


\subsection{Microclimatic Conditions}

As previously mentioned, the effect of the greenhouse microclimatic condition on greenhouse crops, such as tomatoes and cucumbers, has been intensively studied in recent decades [51-55] and will not be reviewed in detail here. However, as warm-season plants are sensitive to diurnal temperature variations, greenhouse cultivation in arid and semiarid regions will involve additional risks and production costs due to wide night and day air temperature differences. Therefore, microclimate control is a critical constituent for the efficient use of energy in greenhouse production (i.e., crop yield per unit of energy), and it is briefly discussed in conjunction with energy requirements. Castilla et al. [56] reported an important increase in tomato production per $\mathrm{m}^{2}$ in "high-tech" climate control greenhouses in the Netherlands $\left(58-60 \mathrm{Kg} \mathrm{m}^{-2}\right)$ compared with Spain $\left(18-25 \mathrm{Kg} \mathrm{m}^{-2}\right.$ ) and Greece (15-20 Kg m${ }^{-2}$ ). To be more useful, not only the physical climate but also the economic environment (prices and labor) should be considered (Table 4).

Table 4. Percentage production cost of the various processes in greenhouse tomato crop in different locations [56,57].

\begin{tabular}{ccccc}
\hline Processes/Input & Spain & Belgium & Greece & Turkey \\
\hline Heating $+\mathrm{CO}_{2}$ & - & $35.0 \%$ & - & - \\
fertilization & & $43.4 \%$ & $12.0 \%$ & $5.9 \%$ \\
Labor cost & $46.0 \%$ & $8.0 \%$ & $3 \%$ & $18.2 \%$ \\
Plant material & $8.5 \%$ & $5.4 \%$ & $18.1 \%$ & $30.5 \%$ \\
Pesticides and fertilizers & $32.5 \%$ & - & $1.0 \%$ & $0.4 \%$ \\
Water & $6.5 \%$ & - & $14.2 \%$ & $12.4 \%$ \\
Electricity & - & - & $51.7 \%$ & $32.6 \%$ \\
Fossil fuels & - & $8.2 \%$ & - & - \\
Other & $6.5 \%$ & &
\end{tabular}

What traditionally happens in Mediterranean countries is that growers try to keep heating costs low during the winter period because of the low market prices for their products. Therefore, the control of the heating temperature in the greenhouse is not based on the quality or quantity of production but mainly on the cost. Thus, the heating system is usually used as an antifreeze tool and not as a production tool (Table 4). In this way, the temperature in the greenhouse in winter is much lower than the ideal temperature, with natural effects on the quality of the products. The relative humidity depends on air temperature. With the same total water content, the lower the air temperature, the higher the relative humidity, so fungal diseases can develop, and there is a need for intervention with pesticides that may burden both the health of consumers and the environment.

Several authors reported on achieving heating energy savings by regulating the greenhouse air temperature. For example, for cucumber, after $5 \mathrm{~h}$ of darkness, it is preferable to decrease the air temperature from 20 to $12{ }^{\circ} \mathrm{C}$ [58]. In another study, Toki et al. [59] indicated that, in tomato, the night air temperature could be set at $16^{\circ} \mathrm{C}$ for $4 \mathrm{~h}$ between 17:00 and 21:00 and then reduced to $10-12{ }^{\circ} \mathrm{C}$.

Energy use due to temperature control can be minimized using temperature integration algorithm systems that allow for temperature ranges over a time period rather than strict temperature setpoints [11]. Today, the greenhouse air temperature is still a matter of interest as it also associated with pollen infertility, growth and yield [55,60]. For the proper fruit set and yield of tomato, Harel et al. [61] suggested a mean daily air temperatures of $25-26^{\circ} \mathrm{C}$. Reducing the mean air temperature by $1-1.5^{\circ} \mathrm{C}$ and increasing the relative humidity from 50 to $70 \%$ improved pollen grain viability. Day-night air temperature difference may have a different response among different cultivars, which should be readjusted during growth, as older plants require a lower temperature for optimal growth and yield [62,63]. According to Abdelmageed and Gruda, [64], a "Summerset" heat-tolerant tomato variety indicated the highest fruit set percentage compared to the least sensitive variety, "UC 82-B", when the air day/night temperatures were $37-27^{\circ} \mathrm{C}$ 
rather than $37-22{ }^{\circ} \mathrm{C}$. It was also demonstrated that the fruit set percentage was directly affected by the number of pollen grains produced and released and, therefore, by night temperatures. Indeed, few data exist on the relative importance of night temperature compared to those on daytime [51].

Root temperature has long been recognized as an important factor for plant growth. The optimum root zone temperature is recommended at $21^{\circ} \mathrm{C}$, although it may be readjusted to crop development stages. Bugbee and White [65] suggested that during the first 4 weeks of tomato growth, the root temperature should be kept in the range of $25-30{ }^{\circ} \mathrm{C}$ and, after that, decreased to $20-25^{\circ} \mathrm{C}$. According to the same authors, tomato growth was severely restricted at a root temperature of $15^{\circ} \mathrm{C}$. Bonachela [66], working in a plastic unheated greenhouse under Mediterranean climatic conditions, concluded that a gravel-sand mulch provides a more suitable soil thermal environment for root growth in comparison with non-mulched soils during the winter period, in addition to reducing soil evaporation and increasing the photosynthetically active radiation (PAR) reflected toward the plants. However, in soilless-based grown crops in plastic containers, root zone temperatures often exceed $40^{\circ} \mathrm{C}$. Therefore, the optimum temperature of the nutrient solution is important, and the air temperature and light intensity in greenhouses should also be considered.

Some researchers reported on rood zone cooling under high air temperature conditions as a method of improving fruit quality by increasing nutrient uptake $[67,68]$. However, Yan et al. [69] suggested that decreasing the root temperature to $10^{\circ} \mathrm{C}$ causes a notable reduction in total nitrogen, potassium and calcium uptake of shoots when compared with treatment conducted at a root temperature of $20^{\circ} \mathrm{C}$.

Figure 3 shows the different types of greenhouses commonly used in the Mediterranean region. Modern greenhouse systems (where the indoor climate can be controlled completely independently of the outdoor climate; Figure 4A) and soilless-based systems (Figure 4B) are increasingly used in some cases, promoting the efficient use of resources. However, since the majority of greenhouses and tunnels are low-to-medium technology (Figure $4 \mathrm{C}, \mathrm{D}$ ), suboptimal growing conditions are usually associated with high addition of fertilizers and pesticides $[9,15]$.

Greenhouses in winter, due to the low outside temperatures, must be kept closed. This leads to accumulation of moisture, increasing the relative humidity of the air up to $100 \%$. The water condenses on the inner face of the polyethylene cover of the greenhouse and drips on the plants, creating favorable conditions for the onset and rapid spread of fungal diseases. Therefore, a relative humidity level of $70-80 \%$ in the greenhouse for cucumber and tomato crops during the winter nights should be sought, using a well-designed control system [29]. A humidity control strategy is needed for the night, as humidity control is the biggest problem that greenhouses face during the winter. Preventing water deposition on plants' surface (leaves etc.) will reduce the appearance of white mildew and botrytis. Despite the use of dehumidification systems in high value-added crops, such as cannabis, or in plant factories, recently there has been increasing interest in using dehumidifiers within greenhouses in semi-arid region as a means of humidity management and generating fresh water by condensation. However, dehumidification systems using a refrigeration cycle is an energy intensive process and, hence, considered as an expensive strategy for greenhouse production $[70,71]$. Hygroscopic materials could also adsorb water vapor and decrease greenhouse air humidity. However, as cited by Amani et al. [71], their application pertains to their high cost and practical challenges, such as the heat required for the regeneration of the hygroscopic material. 


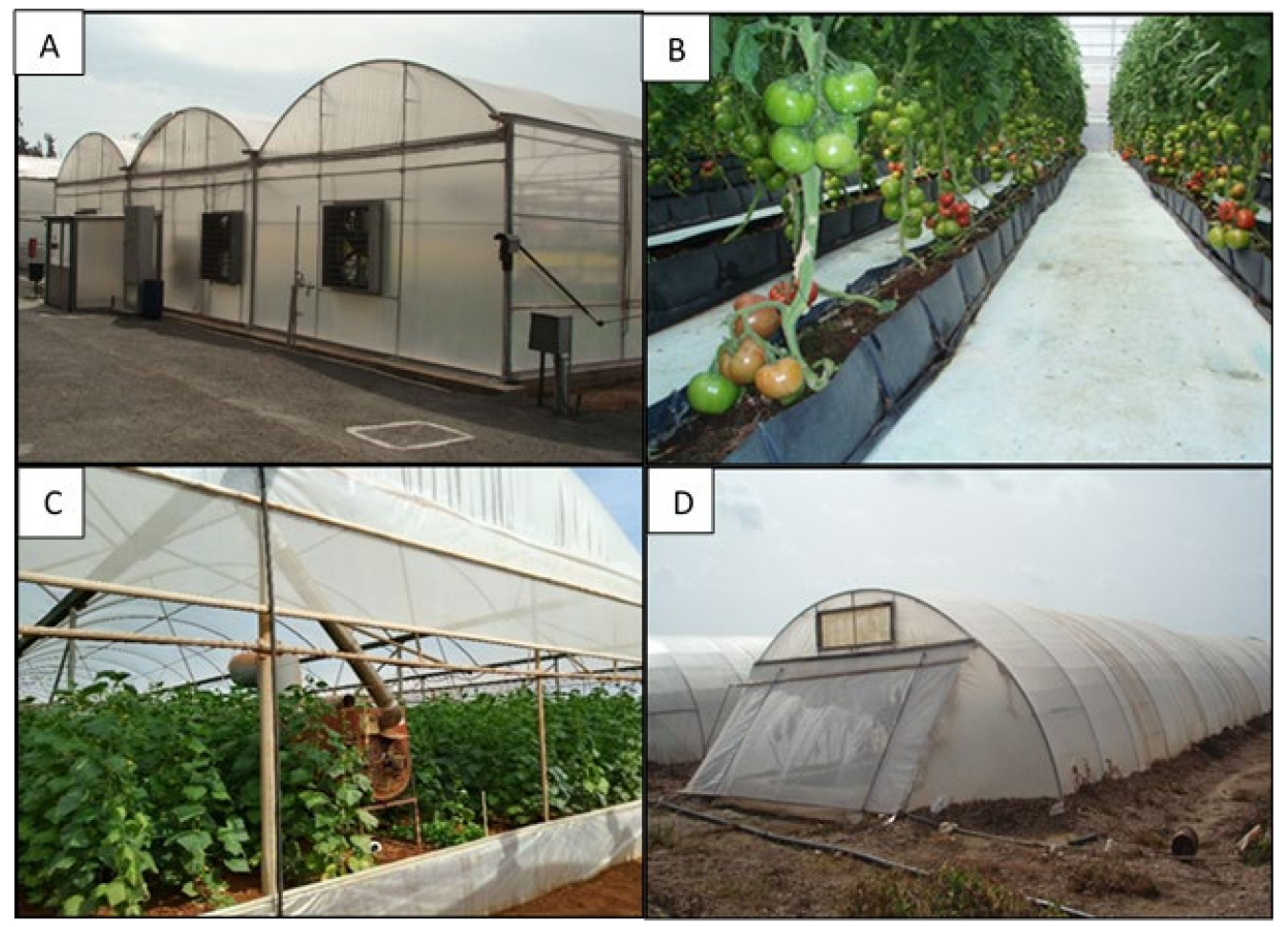

Figure 4. Greenhouse construction types and climate equipment used; high-tech greenhouse with automated side-wall opening and forced air ventilation system (A); a soilless tomato-growing system (B); greenhouse side opening manually operated with no netting in openings (C); a high tunnel greenhouse with minimum climate equipment used and no side wall aeration (D).

Taking into account both temperature and humidity measurements, fine regulation of vapor pressure deficit (VPD) can be a crucial factor for the successful growing of plants in a greenhouse. A considerable amount of research work conducted in recent years has evaluated the effect of VPD on transpiration, plant grown and production, and water productivity. VPD has been widely recognized as the driving force of water loss from a leaf and a parameter describing the climate conditions favorable for the development of fungal crop diseases and several crop physiological disorders [72,73]. Optimal VPD values for tomato and cucumber are suggested to be in the range of 0.3 to $1.0 \mathrm{kPa}$ [52]. For instance, Lu et al. [74] suggested that, in a winter cropping period, reducing VPD from 1.4 to $0.8 \mathrm{kPa}$ at midday increased the mean tomato biomass by $17.3 \%$ and yield by $12.3 \%$. Indeed, Katsoulas and Kittas [51] pointed out that higher VPD values negatively affected stomatal conductance functioning and photosynthesis rate. Continuously low VPD values combined with inconsistent soil moisture, low transpiration rates and high air relative humidity values are often associated with calcium deficiency in tomato (i.e., blossom end rot). A comprehensive review of greenhouse microclimate control based on VPD values for different crop stages of tomato is available in the work of Shamshiri et al. [52]. For cucumbers, Song et al. [69] suggested maintaining VPD below $1.5 \mathrm{kPa}$, which leads to greater accumulation of dry matter, an improved net photosynthetic rate and a reduced rate of transpiration. However, Nikolaou et al. [75] and Shibuya et al. [76], working with a soilless cucumber crop, suggested that maintaining mean VPD values at $2 \mathrm{kPa}$ will help to alleviated the excessive heat at midday due to higher transpiration rates, with no negative effect on yield. Lower VPD under higher irrigation salinity could also help alleviate salinity effects by reducing water uptake [77]. However, VPD is also related to greenhouse heating and dehumidification energy consumption costs. The work of Trigui et al. [78], who evaluated the effects of different values of VPDs on tomato energy cost versus revenue, is relevant. These authors justify the development of a model to predict plant yield and energy consumption based on VPD values. 
Despite the fact that many techniques have been used to increase greenhouse air $\mathrm{CO}_{2}$ concentrations (i.e., $\mathrm{CO}_{2}$ enrichment), most are of expensive with certain limitations and drawbacks [79]. Indeed, the $\mathrm{CO}_{2}$ concentration in a well-sealed greenhouse during winter considerably decreased to half the ambient air concentration and even less within the crop canopy, and it is considered the most important limiting factor for photosynthesis [80,81]. In Spain, the reduction in the production of a tomato crop caused by $\mathrm{CO}_{2}$ depletion during winter could be compared to the reduction resulting from a lower ambient air temperature caused by ventilation to avoid depletion. Compensating for the effect of depletion is much cheaper than making up the loss by heating [82]. Sánchez-Guerrero et al. [83], working with a soilless cucumber crop in a plastic greenhouse under Mediterranean climatic conditions, indicated that by increasing $\mathrm{CO}_{2}$ to $700 \mu \mathrm{mol} \mathrm{mol}^{-1}$, the cucumber yield was increased by $19 \%$ and an increase of $40 \%$ in water use efficiency was obtained in comparison with a non- $\mathrm{CO}_{2}$ enriched greenhouse. In England, the injection of $1000 \mathrm{ppm}$ of $\mathrm{CO}_{2}$ resulted in a $23 \%$ increase in cucumber fruit weight [84]. Upper threshold $\mathrm{CO}_{2}$ values were set at $1500 \mathrm{ppm}$ for cucumber and $2200 \mathrm{ppm}$ for tomato, which were also affected by the light intensity [84]. In addition, Yang et al. [85] suggested that $\mathrm{CO}_{2}$ enrichment under limited irrigation water application could result in water savings, nutritional and health quality improvements in tomato and the alleviation of salinity stress in cucumber. Zhang et al. [86] also suggested that $\mathrm{CO}_{2}$ enrichment can effectively alleviate nutrient stress in tomato seedlings and considered it as a feasible strategy to manage secondary salinization in protected vegetable production. The problem in the Mediterranean region is that it is necessary to open windows for almost the whole day to avoid high temperatures. However, some authors advise supplying $\mathrm{CO}_{2}$ to maintain different levels depending on the ventilation requirements. On the one hand, they concluded that enrichment is useful even during periods when it is needed to keep windows open. These authors recommended maintaining a low atmospheric value. On the other hand, they suggested maintaining the levels at about 700-800 $\mu \mathrm{mol} \mathrm{mol}^{-1}$ via $\mathrm{CO}_{2}$ enrichment when the greenhouse can be closed (usually in the early morning and the late afternoon).

The typical evolution of $\mathrm{CO}_{2}$ concentration in greenhouse air, in a free ventilated greenhouse under Mediterranean climatic conditions with cucumber cultivation, is plotted in Figure 5, which shows the variation in $\mathrm{CO}_{2}$ levels during the day without an artificial $\mathrm{CO}_{2}$ supply (Cyprus Agricultural Research Institute, unpublished data). When there is a low ventilation rate and high solar irradiation, $\mathrm{CO}_{2}$ can sink to very low levels that can affect plant growth and final yield production per drop of water and unit of energy. Ventilating a greenhouse under sunny but chilly days implies a trade-off between inflow of $\mathrm{CO}_{2}$ and maintaining an adequate temperature within the greenhouse [82].

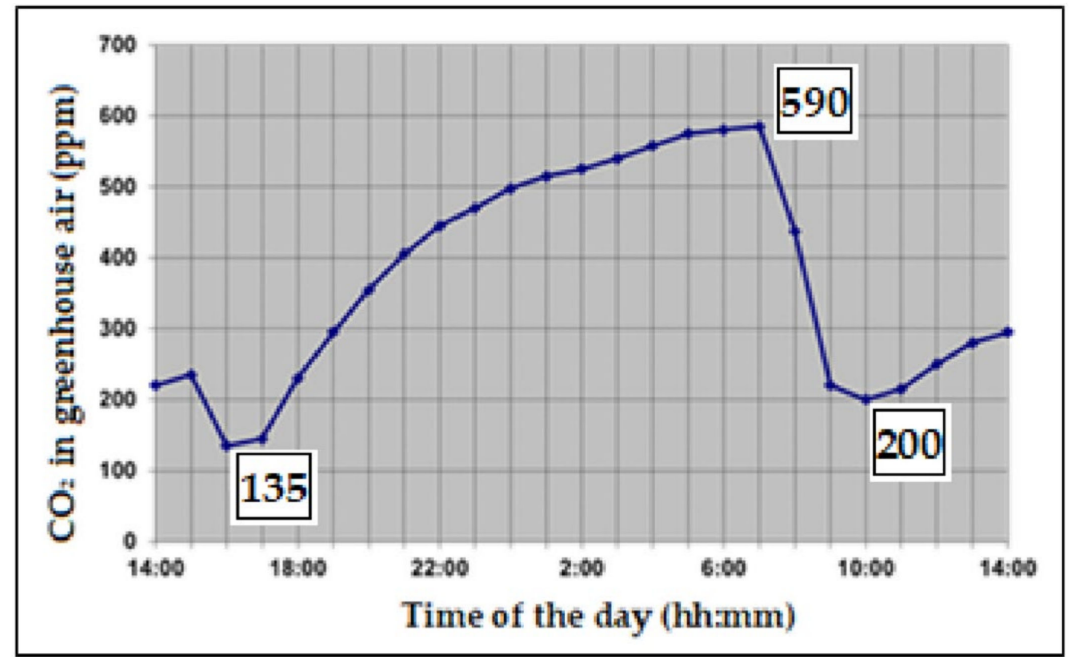

Figure 5. Usual evolution of $\mathrm{CO}_{2}$ levels in a free ventilated greenhouse with cucumber crop in the Mediterranean (Cyprus). 
Regulating $\mathrm{CO}_{2}$ concentrations in the greenhouse air with the aim of increasing production per unit of energy could be possible in the Mediterranean only if electricity and/or $\mathrm{CO}_{2}$ prices are relatively cheap and closed greenhouses are used [87].

Modifying the greenhouse microclimate by controlling air temperature, $\mathrm{CO}_{2}$ concentration, and air humidity through ventilation and air circulation systems affects crop canopy resistance values and transpiration [88]. Nevertheless, leaf conductance was $25 \%$ higher in greenhouses cooled by employing wet evaporative pads. In such greenhouses, higher transpiration rates were obtained for cucumber compared to greenhouses with ventilation (an increase of up to $60 \%$ ) [89]. Indeed, increasing the greenhouse coupling (an indicator of greenhouse ventilation requirements) by $1 \%$ increases the amount of water needed to produce $1 \mathrm{~kg}$ of tomato by about $0.8 \mathrm{~L}$ [90]. Thongbai et al. [91] pointed out that increasing the air circulation from 0.3 to $1.0 \mathrm{~m} \mathrm{~s}^{-1}$ raises the net photosynthetic rate of tomato seedlings by $62-76 \%$, with similar effects as those caused by increasing the $\mathrm{CO}_{2}$ concentration from 273 to $545 \mu \mathrm{mol} \mathrm{mol}^{-1}$. However, the pattern of the air circulation system has no effect on tomato yield compared to an elevated $\mathrm{CO}_{2}$ concentration [92]. In another case, a passive wind catcher integrated into a greenhouse combined with an evaporative cooling system could provide higher airflow rates as compared to the use of side openings and reducing the average indoor air temperature by a maximum of $17^{\circ} \mathrm{C}$ [93].

\section{Energy-Efficient Measures}

Recommendations for increasing energy efficiency and decreasing energy consumption in greenhouse constructions in semiarid Mediterranean countries are as follows:

- An East-West greenhouse orientation may be the optimum orientation in the Mediterranean in relation to energy needs, as it can reduce the annual cost of air-conditioning of greenhouses compared to the North-South orientation [94]. Nevertheless, the above recommendation is related to the prevailing wind direction, and it may not be the case for areas where the north wind direction prevails. In addition, although an East-West orientation of the greenhouse may be optimum for energy saving purposes, it may not be the optimum in relation to the maximization of the incoming solar radiation.

- A pad and fan cooling system has high efficiency in dry ambient conditions but not in humid conditions. The recommended area of the pad in semi-arid and arid regions, should be $1 \mathrm{~m}^{2}$ for every $20-30 \mathrm{~m}^{2}$ of greenhouse ground cover area, with a pad thickness higher than $150 \mathrm{~mm}$. The pad-to-fan distance should be less than $40-48 \mathrm{~m}$ with an airflow rate of $120-150 \mathrm{~m}^{3} \mathrm{~m}^{-2} \mathrm{~h}^{-1}$ of the greenhouse area [13].

- $\quad$ Fog and mist systems present higher cooling uniformity within the crop canopy as opposed to pad- and fan-cooled greenhouses. High-pressure fog systems are more effective for controlling the greenhouse climate as opposed to low pressure. However, during the operation of the fog system, a vent opening of $20 \%$ of the maximum aperture should be maintained [13,95].

- $\quad$ Side-wall openings of natural ventilation should be located in line with the prevailing wind direction. In the case of low external air velocity wind, natural ventilation could create a cooler and more humid environment around the crop canopy than that produced by forced-air ventilation systems.

- The forced air ventilation system should develop a capacity of about 30 Pa static pressure, with the distance between the two fans being less than $10 \mathrm{~m}$. The opposite side opening should be at least 1.25 times the fan area. Air speed should not exceed $0.5 \mathrm{~m} \mathrm{~s}^{-1}$, as it induces stress to plants [13].

- $\mathrm{CO}_{2}$ enrichment has a significant effect on crop growth and production. This effect has been proved in levels up to $700-1000 \mu \mathrm{mol} \mathrm{mol}^{-1}$. If there is no artificial $\mathrm{CO}_{2}$ source available, this can also be achieved by a good ventilation of the greenhouse $[13,81]$.

- Low-pressure inexpensive fogging systems, used for a constant reduction in VPD, could be applied in low-technology greenhouses. Care should be taken in regard to the droplet size of the fog so that leaves remain dry [56]. 
- The total ventilator area should not be more than $30 \%$ of floor area. It should be located at the ridge, on the sidewalls and the gable. When solar radiation values exceed $900 \mathrm{~W} \mathrm{~m}^{-2}$, a ventilation rate of $0.06 \mathrm{~m}^{3} \mathrm{~s}^{-1} \mathrm{~m}^{-2}$ for a greenhouse with a mean height of $3 \mathrm{~m}$ is recommended to maintain the difference in the internal-external air temperature of about $4{ }^{\circ} \mathrm{C}$ [13].

- Near-infrared-reflecting plastic films seem to be the most suitable, low-cost and simple cover for greenhouses under arid conditions. The use of anti-drop covering materials is an alternative method for greenhouse dehumidification. The use of inflated cover is very scarce, as greenhouses should be properly isolated. In addition, inflated cover reduces available light [13].

- Heating pipes under the plants is better than heating them on top of the greenhouse, where in combination with greenhouse fans, the heat from the greenhouse ceiling can circulate to the floor, preventing plants from becoming wet by condensation. In any case, the use of a mixed heating system (air heater and heating pipes) has proved to be more suitable for heating a greenhouse tunnel. Despite increased energy consumption, the use of a mixed heating system improves the control of both air temperature and humidity, particularly by keeping the inside air's dew point temperature lower than the cover temperature and preventing the occurrence of condensation on the plastic films [96].

- A solar passive water-sleeve heating system can be used as an eco-friendly tool to prevent intensive use of fossil fuels and a negative effect on the environment [97], and it is also suitable for anti-frost protection of crops [98,99].

- Flexible climate control system cases are frequency drive (VFD) controllers. These may be used as energy-saving tools [14].

- Shading screens and whitewashing of greenhouse roofs for periods with high radiation reduce the cooling requirements. Thermal screens can decrease the use of fossil fuels for heating greenhouses and air humidity levels; therefore, it is recommended to open them before the operation of the forced-air ventilation system [36].

- Greenhouse semitransparent photovoltaic modules can supply around 16 and $44 \%$ of the total electrical annual demand and the yearly air conditioning electrical needs, respectively. The use of greenhouse photovoltaic panels in the greenhouse roof gutter with a shading intensity of no more than $15-20 \%$ is a promising technique [100].

- The economic analysis in terms of investment and energy saving of an active solar heating system indicates that it is cost effective for plastic greenhouses [101].

- The use of mulching contributes to a reduction in air humidity and minimizes water evaporation from the soil surface. However, mulching with white plastic film is not recommended in unheated greenhouses when the soil temperature can be a limiting factor for plant growing.

- Biodegradable mulch is a competitive alternative to plastic mulch from the perspective of sustainable development [102].

\section{Conclusions}

Over the past few decades, there has been a significant increase in the greenhouse vegetable industry in the Mediterranean region, which has the advantage of yearly high light intensity conditions. Fresh, off-season production of cucumber and tomato fruits, contributing toward many countries' food security, offers growers very enticing prices. However, due to unfavorable indoor climatic conditions, the production of warm species often becomes problematic.

Greenhouse redesign under local climatic conditions for better control of the indoor climate and energy use efficiency are the most important challenges in the region. The current review article highlights the importance of the utilization of potential renewable energy systems (i.e., geothermal, solar and wind) in the design of the greenhouse energy profile, modifying the microclimatic conditions for optimization of yield per unit of energy. The replacement of fossil fuels by other sustainable sources concerns the reliability of the 
availability/delivery of alternative sources and their price fluctuations, since, in general, investment costs related to this step are generally (very) high. For economic reasons (economy of scale), the application of more sustainable energy sources generally requires a connection to a large greenhouse area.

Author Contributions: Conceptualization, N.K., G.N. and D.N.; writing-original draft preparation, G.N. and D.N.; writing — review and editing, G.N., D.N., P.P., A.C., E.K. and N.K.; supervision, N.K.; project administration, N.K.; funding acquisition, N.K. All authors have read and agreed to the published version of the manuscript.

Funding: The work is carried out in the frame of the PRECIMED project that is funded by the General Secretariat for Research and Technology of the Ministry of Development and Investments of Greece under the PRIMA Programme. PRIMA is an Art.185 initiative supported and co-funded under Horizon 2020, the European Union's Programme for Research and Innovation. Project Acronym/Code: “PRECIMED-Prima2018-09" (project application number: 155331/I4/19.09.18).

Institutional Review Board Statement: Not applicable.

Informed Consent Statement: Not applicable.

Data Availability Statement: Not applicable.

Conflicts of Interest: The authors declare no conflict of interest.

\section{References}

1. Franco, A.; Valera, D.; Peña, A. Energy Efficiency in Greenhouse Evaporative Cooling Techniques: Cooling Boxes versus Cellulose Pads. Energies 2014, 7, 1427-1447. [CrossRef]

2. Sánchez, J.A.; Reca, J.; Martínez, J. Water productivity in a mediterranean semi-arid greenhouse district. Water Resour. Manag. 2015, 29, 5395-5411. [CrossRef]

3. Gázquez, J.C.; López, J.C.; Pérez-Parra, J.J.; Baeza, E.J.; Saéz, M.; Parra, A. Greenhouse Cooling Strategies for Mediterranean Climate Areas. Acta Hortic. 2008, 801, 425-432. [CrossRef]

4. Abdel-Ghany, A.M.; Al-Helal, I.M.; Alzahrani, S.M.; Alsadon, A.A.; Ali, I.M.; Elleithy, R.M. Covering Materials Incorporating Radiation-Preventing Techniques to Meet Greenhouse Cooling Challenges in Arid Regions. Sci. World J. 2012, 2012, 906360. [CrossRef] [PubMed]

5. Granadosa, M.R.; Bonachela, S.; Hernández, J.; López, J.C.; Magán, J.J.; Baeza, E.J.; Gázquez, J.C.; Pérez-Parra, J.J. Soil temperatures in a mediterranean greenhouse with different solarization strategies. Acta Hortic. 2012, 927, 747-754. [CrossRef]

6. Teitel, M.; Baeza, E.J.; Montero, J.I. Greenhouse design: Concepts and trends. Acta Hortic. 2012, 952, 605-620. [CrossRef]

7. Maraveas, C. Environmental sustainability of greenhouse covering materials. Sustainability 2019, 11, 6129. [CrossRef]

8. Roble, C. Only $9 \%$ of greenhouse acreage worldwide is covered with glass. Hortidaily 2020. Available online: https:/ /www. hortidaily.com/article/6041956/only-9-of-greenhouse-acreage-worldwide-is-covered-with-glass/ (accessed on 17 June 2021).

9. Pardossi, A.; Tognoni, F.; Incrocci, L. Mediterranean Greenhouse Technology. Chron. Hortic. 2004, 44, 28-34.

10. Abdalla, N.; Taha, N.; El-Ramady, H.; Bayoumi, Y. Management of Heat Stress in Tomato Seedlings under Arid and Semi-Arid Regions: A Review. Environ. Biodivers. Soil Secur. 2020, 4, 47-58. [CrossRef]

11. Iddio, E.; Wang, L.; Thomas, Y.; McMorrow, G.; Denzer, A. Energy efficient operation and modeling for greenhouses: A literature review. Renew. Sustain. Energy Rev. 2020, 117, 109480. [CrossRef]

12. Enoch, H.Z. A Theroy for Optimalization of Primary Production in Protected Cultivation: Influence of Aerial Environment Upon Primary Plant Production. Acta Hortic. 1997, 76, 31-44.

13. Papasolomontos, A.; Baudoin, W.; Lutaladio, N.; Castilla, N. 2013 Greenhouse climate control and energy use. In Good Agricultural Practices for Greenhouse Vegetable Crops. Principles for Mediterranean Climate Areas; Baudoin, W., Nono-Womdim, R., Lutaladio, N., Hodder, A., Castilla, N., Leonardi, C., De Pascale, S., Qaryouti, M., Duffy, R., Eds.; Food and Agriculture Organization of the United Nations: Rome, Italy, 2013; pp. 63-97.

14. Villarreal-Guerrero, F.; Pinedo-Alvarez, A.; Flores-Velázquez, J. Control of greenhouse-air energy and vapor pressure deficit with heating, variable fogging rates and variable vent configurations: Simulated effectiveness under varied outside climates. Comput. Electron. Agric. 2020, 174, 105515. [CrossRef]

15. Weldegiorgis, L.G.; Mezgebo, G.K.; Gebremariam, H.G.E.; Kahsay, Z.A. Resources Use Efficiency of Irrigated Tomato Production of Small-scale Farmers. Int. J. Veg. Sci. 2018, 24, 456-465. [CrossRef]

16. Perry, C. Learning from Water Footprints: Who loses, who wins, and who cares? Policy Q. 2019, 15, 70-74. [CrossRef]

17. Hassanien, R.; Hassanien, E.; Li, M.; Dong, W. Advanced applications of solar energy in agricultural greenhouses. Renew. Sustain. Energy Rev. 2016, 54, 989-1001. [CrossRef]

18. Ahamed, M.S.; Guo, H.; Tanino, K. Energy saving techniques for reducing the heating cost of conventional greenhouses. Biosyst. Eng. 2019, 178, 9-33. [CrossRef] 
19. Stanghellini, C.; Baptista, F.; Eriksson, E.; Gilli, C.; Giuffrida, F.; Kempkes, F.; Muñoz, P.; Stepowska, A.; Montero, J.I. Sensible Use of Primary Energy in Organic Greenhouse Production; BioGreenhouse COST Action FA 1105; COST: Brussels, Belgium, 2016; ISBN 9789462575356.

20. IPCC Global warming of $1.5^{\circ} \mathrm{C}$ : An IPCC Special Report on the impacts of global warming of $1.5^{\circ} \mathrm{C}$ above pre-industrial levels, Geneva. 2018. Ipcc - Sr15 (p. 32). Available online: https://report.ipcc.ch/sr15/pdf/sr15_spm_final.pdf\%0Ahttp: //www.ipcc.ch/report/sr15/ (accessed on 20 November 2021).

21. Mohamed, E.S.; Markou, G.; Balafoutis, T.; Papadakis, G.; Michael, P.; Janssen, R. Energy Savings Potential in Cyprus. Floriculture and Vegetables in Greenhouses. Current Situation and Energy Saving Measures in Combination with RES.; WIP GmbH \& Co Planungs KG: Muenchen, Germany, 2017.

22. Yildirim, N.; Bilir, L. Evaluation of a hybrid system for a nearly zero energy greenhouse. Energy Convers. Manag. 2017, 148, 1278-1290. [CrossRef]

23. European Union. Directive 2009/28/EC-Renewable Energy Directive. Available online: http:/ / eur-lex.europa.eu/legalcontent/EN/ALL/?uri=CELEX:32009L0028 (accessed on 11 November 2021).

24. Rastegarpour, S.; Scattolini, R.F.L. Performance improvement of an air-to-water heat pump through linear time-varying MPC with adaptive COP predictor. J. Process Control 2021, 99, 69-78. [CrossRef]

25. Le, A.T.; Wang, L.; Wang, Y.; Li, D. Measurement investigation on the feasibility of shallow geothermal energy for heating and cooling applied in agricultural greenhouses of Shouguang City:Ground temperature profiles and geothermal potential. Inf. Process. Agric. 2021, 8, 251-269.

26. Adapt Agricultural Production to Climate Change and Limited Water Supply. Available online: https://www.adapt2change.org/ en/home (accessed on 16 June 2021).

27. Florides, G.; Kalogirou, S.; Theophilou, K.; Evangelos, E. Analysis of the typical meteorological year (TMY) of Cyprus. In Proceedings of the Eighth International IBPSA Conference, Eindhoven, The Netherlands, 11-14 August 2003; pp. 339-346.

28. Montero, J.I.; Short, T.H. A comparison of solar heated greenhouses in Wooster, Ohio, USA, and Malaga (Southern Spain). Acta Hortic. 1984, 148, 805-814. [CrossRef]

29. Polycarpou, P. Optimization of nocturnal climate management in PE greenhouses in Cyprus. Acta Hortic. 2004, 691, 815-820. [CrossRef]

30. Aroca-Delgado, R.; Pérez-Alonso, J.; Callejón-Ferre, Á.J.; Velázquez-Martí, B. Compatibility between crops and solar panels: An overview from shading systems. Sustainability 2018, 10, 743. [CrossRef]

31. Ureña-Sánchez, R.; Callejón-Ferre, Á.J.; Pérez-Alonso, J.; Carreño-Ortega, Á. Greenhouse tomato production with electricity generation by roof-mounted flexible solar panels. Sci. Agric. 2012, 69, 233-239. [CrossRef]

32. La Notte, L.; Giordano, L.; Calabrò, E.; Bedini, R.; Colla, G.; Puglisi, G.; Reale, A. Hybrid and organic photovoltaics for greenhouse applications. Appl. Energy 2020, 278, 115582. [CrossRef]

33. Ezzaeri, K.; Fatnassi, H.; Wifaya, A.; Bazgaou, A.; Aharoune, A.; Poncet, C.; Bekkaoui, A.; Bouirden, L. Performance of photovoltaic canarian greenhouse: A comparison study between summer and winter seasons. Sol. Energy 2020, 198, 275-282. [CrossRef]

34. López, J.C.; Fernandéz, M.D.; Abad, D.M.M.; Magán, J.J.; González, M.; Montero, J.I.; Anton, Á.; Stanghellini, C.; Kempkes, F.L.K. DSS for Optimum Ventilation, Thermal Storage \& CO2 Management for Different Climates \& Available Sustainable Energy Sources; European Commission: Brussels, Belgium, 2012. Available online: http:/ /www.wageningenur.nl/en/Research-Results/Projectsand-programmes/Euphoros-1/Reports.htm (accessed on 16 June 2021).

35. Cuce, E.; Harjunowibowo, D.; Cuce, P.M. Renewable and sustainable energy saving strategies for greenhouse systems: A comprehensive review. Renew. Sustain. Energy Rev. 2016, 64, 34-59. [CrossRef]

36. Taki, M.; Yildizhan, H. Evaluation the sustainable energy applications for fruit and vegetable productions processes; case study: Greenhouse cucumber production. J. Clean. Prod. 2018, 199, 164-172. [CrossRef]

37. Gorjian, S.; Calise, F.; Kant, K.; Ahamed, M.S.; Copertaro, B.; Najafi, G.; Zhang, X.; Aghaei, M.; Shamshiri, R.R. A review on opportunities for implementation of solar energy technologies in agricultural greenhouses. J. Clean. Prod. 2021, $285,124807$. [CrossRef]

38. Omar, M.N.; Taha, A.T.; Samak, A.A.; Keshek, M.H.; Gomaa, E.M.; Elsisi, S.F. Simulation and validation model of cooling greenhouse by solar energy ( $\mathrm{PV}$ ) integrated with painting its cover and its effect on the cucumber production. Renew. Energy 2021, 172, 1154-1173. [CrossRef]

39. Ahemd, H.A.; Al-faraj, A.A.; Abdel-ghany, A.M. Scientia Horticulturae Shading greenhouses to improve the microclimate, energy and water saving in hot regions: A review. Sci. Hortic. 2016, 201, 36-45. [CrossRef]

40. Nikolaou, G.; Neocleous, D.; Katsoulas, N.; Kittas, C. Dynamic assessment of whitewash shading and evaporative cooling on the greenhouse microclimate and cucumber growth in a Mediterranean climate. Ital. J. Agrometeorol. 2018, 2, 15-26. [CrossRef]

41. Kitta, E.; Katsoulas, N. Effect of shading on photosynthesis of greenhouse hydroponic cucumber crops. Ital. J. Agrometeorol. 2020, 2020, 41-48. [CrossRef]

42. Kläring, H.P.; Klopotek, Y.; Schmidt, U.; Tantau, H.-J. Screening a cucumber crop during leaf area development reduces yield. Ann. Appl. Biol. 2012, 161, 161-168. [CrossRef]

43. Development of Greenhouse Foils and Additives to Optimize Plant Growth and Disease Inhibition through the Control of Photomorphogenesis. Available online: https: / / cordis.europa.eu/project/id/QLK5-CT-2001-70496 (accessed on 25 November 2021). 
44. Kittas, C.; Tchamitchian, M.; Katsoulas, N.; Karaiskou, P.; Papaioannou, C. Effect of two UV-absorbing greenhouse-covering films on growth and yield of an eggplant soilless crop. Sci. Hortic. 2006, 110, 30-37. [CrossRef]

45. Dáder, B.; Gwynn-Jones, D.; Moreno, A.; Winters, A.; Fereres, A. Impact of UV-A radiation on the performance of aphids and whiteflies and on the leaf chemistry of their host plants. J. Photochem. Photobiol. B Biol. 2014, 138, 307-316. [CrossRef] [PubMed]

46. Luthria, D.L.; Mukhopadhyay, S.; Krizek, D.T. Content of total phenolics and phenolic acids in tomato (Lycopersicon esculentum Mill.) fruits as influenced by cultivar and solar UV radiation. J. Food Compos. Anal. 2006, 19, 771-777. [CrossRef]

47. Abd El-Aal, H.A.; Rizk, A.M.; Mousa, I.E. Evaluation of new greenhouse covers with modified light regime to control cotton aphid and cucumber (Cucumis sativus L.) productivity. Crop Prot. 2018, 107, 64-70. [CrossRef]

48. Qian, M.; Rosenqvist, E.; Flygare, A.M.; Kalbina, I.; Teng, Y.; Jansen, M.A.K.; Strid, Å. UV-A light induces a robust and dwarfed phenotype in cucumber plants (Cucumis sativus L.) without affecting fruit yield. Sci. Hortic. 2020, 263, 109110. [CrossRef]

49. Palmitessa, O.D.; Paciello, P.; Santamaria, P. Supplemental LED increases tomato yield in mediterranean semi-closed greenhouse. Agronomy 2020, 10, 1353. [CrossRef]

50. Bruggink, G.T.; Heuvelink, E. Influence of light on the growth of young tomato, cucumber and sweet pepper plants in the greenhouse: Effects on relative growth rate, net assimilation rate and leaf area ratio. Sci. Hortic. 1987, 31, 161-174. [CrossRef]

51. Katsoulas, N.; Kittas, C. Impact of Greenhouse Microclimate on Plant Growth and Development with Special Reference to the Solanaceae. Eur. J. Plant Sci. Biotechnol. 2008, 2, 31-44.

52. Shamshiri, R.R.; Jones, J.W.; Thorp, K.R.; Ahmad, D.; Man, H.C.; Taheri, S. Review of optimum temperature, humidity, and vapour pressure deficit for microclimate evaluation and control in greenhouse cultivation of tomato: A review. Int. Agrophys. 2018, 32, 287-302. [CrossRef]

53. Taha, N.; Abdalla, N.; Bayoumi, Y.; El-Ramady, H. Management of Greenhouse Cucumber Production under Arid Environments: A Review. Environ. Biodivers. Soil Secur. 2020, 4, 123-126. [CrossRef]

54. Huang, S.; Yan, H.; Zhang, C.; Wang, G.; Acquah, S.J.; Yu, J.; Li, L.; Ma, J.; Darko, R.O. Modeling evapotranspiration for cucumber plants based on the Shuttleworth-Wallace model in a Venlo-type greenhouse. Agric. Water Manag. 2020, 228, 105861. [CrossRef]

55. Ruiz-Nieves, J.M.; Ayala-Garay, O.J.; Serra, V.; Dumont, D.; Vercambre, G.; Génard, M.; Gautier, H. The effects of diurnal temperature rise on tomato fruit quality. Can the management of the greenhouse climate mitigate such effects? Sci. Hortic. 2020, 278, 109836. [CrossRef]

56. Castilla, N.; Hernández, J.; Abou-Hadid, A.F. Strategic crop and greenhouse management in mild winter climate areas. Acta Hortic. 2004, 633, 183-196. [CrossRef]

57. Ozkan, B.; Kurklu, A.; Akcaoz, H. An input-output energy analysis in greenhouse vegetable production: A case study for Antalya region of Turkey. Biomass Bioenergy 2004, 26, 89-95. [CrossRef]

58. Van de Vooren, J.; de Lint, P.J.A.L. Challa, H. Influence of varying night temperatures on a cucumber crop. Acta Hortic. 1978, 87, 249-256. [CrossRef]

59. Toki, T.; Ogiwara, S.; Aoki, H. Effect of varying night temperature on the growth and yields in cucumber. Acta Hortic. 1978, 87, $233-238$. [CrossRef]

60. Bita, C.E.; Gerats, T. Plant tolerance to high temperature in a changing environment: Scientific fundamentals and production of heat stress-tolerant crops. Front. Plant Sci. 2013, 4, 273. [CrossRef] [PubMed]

61. Harel, D.; Fadida, H.; Slepoy, A.; Gantz, S.; Shilo, K. The Effect of Mean Daily Temperature and Relative Humidity on Pollen, Fruit Set and Yield of Tomato Grown in Commercial Protected Cultivation. Agronomy 2014, 4, 167-177. [CrossRef]

62. Seginer, I. Transpirational cooling of a greenhouse crop with partial ground cover. Agric. For. Meteorol. 1994, 71, $265-281$. [CrossRef]

63. Papadopoulos, A.P.; Hao, X. Effects of day and night air temperature on growth, productivity and energy use of long English cucumber. Can. J. Plant Sci. 2000, 80, 143-150. [CrossRef]

64. Abdelmageed, A.H.A.; Gruda, N. Influence of high temperatures on gas exchange rate and growth of eight tomato cultivars under controlled heat stress conditions. Eur. J. Hortic. Sci. 2009, 74, 152-159.

65. White, B.B.; White, J.W. Tomato growth as affected by root-zone temperature and the addition of gibberellic acid and kinetin to nutrient solutions. J. Am. Soc. Hortic. Sci. Am. Soc. Hortic. Sci. 1984, 109, 121-125.

66. Bonachela, S.; López, J.C.; Granados, M.R.; Magán, J.J.; Hernández, J.; Baille, A. Effects of gravel mulch on surface energy balance and soil thermal regime in an unheated plastic greenhouse. Biosyst. Eng. 2020, 192, 1-13. [CrossRef]

67. Kawasaki, Y.; Matsuo, S.; Suzuki, K.; Kanayama, Y.; Kanahama, K. Root-zone cooling at high air temperatures enhances physiological activities and internal structures of roots in young tomato plants. J. Jpn. Soc. Hortic. Sci. 2013, 82, 322-327. [CrossRef]

68. Al-Rawahy, M.S.; Al-Rawahy, S.A.; Al-Mulla, Y.A.; Nadaf, S.K. Effect of Cooling Root-Zone Temperature on Growth, Yield and Nutrient Uptake in Cucumber Grown in Hydroponic System During Summer Season in Cooled Greenhouse. J. Agric. Sci. 2018, 11, 47. [CrossRef]

69. Yan, Q.; Duan, Z.; Mao, J.; Li, X.; Dong, F. Effects of root-zone temperature and N, P, and K supplies on nutrient uptake of cucumber (Cucumis sativus L.) seedlings in hydroponics. Soil Sci. Plant Nutr. 2012, 58, 707-717. [CrossRef]

70. Ghani, S.; Bakochristou, F.; ElBialy, E.M.A.A.; Gamaledin, S.M.A.; Rashwan, M.M.; Abdelhalim, A.M.; Ismail, S.M. Design challenges of agricultural greenhouses in hot and arid environments-A review. Eng. Agric. Environ. Food 2019, 12, 48-70. [CrossRef] 
71. Amani, M.; Foroushani, S.; Sultan, M.; Bahrami, M. Comprehensive review on dehumidification strategies for agricultural greenhouse applications. Appl. Therm. Eng. 2020, 181, 115979. [CrossRef]

72. Zhang, T.; Wang, J.; Teng, Y. Adaptive effectiveness of irrigated area expansion in mitigating the impacts of climate change on crop yields in northern China. Sustainability 2017, 9, 851. [CrossRef]

73. Konopacki, P.J.; Treder, W.; Klamkowski, K. Comparison of vapour pressure deficit patterns during cucumber cultivation in a traditional high PE tunnel greenhouse and a tunnel greenhouse equipped with a heat accumulator. Span. J. Agric. Res. 2018, 16, 4. [CrossRef]

74. Lu, N.; Nukaya, T.; Kamimura, T.; Zhang, D.; Kurimoto, I.; Takagaki, M.; Maruo, T.; Kozai, T.; Yamori, W. Control of vapor pressure deficit (VPD) in greenhouse enhanced tomato growth and productivity during the winter season. Sci. Hortic. 2015, 197, 17-23. [CrossRef]

75. Nikolaou, G.; Neocleous, D.; Katsoulas, N.; Kittas, C. Effects of cooling systems on greenhouse microclimate and cucumber growth under mediterranean climatic conditions. Agronomy 2019, 9, 300. [CrossRef]

76. Shibuya, T.; Sugimoto, A.; Kitaya, Y.; Kiyota, M.; Nagasaka, Y.; Kawaguchi, S. Measurement of leaf vapor conductance of cucumber transplants in the greenhouse with minimal invasion. HortScience 2010, 45, 460-462. [CrossRef]

77. Romero-Aranda, R.; Soria, T.; Cuartero, J. Greenhouse mist improves yield of tomato plants grown under saline conditions. J. Am. Soc. Hortic. Sci. 2002, 127, 644-648. [CrossRef]

78. Triguii, M.; Barringtoni, S.F.; Gauthier, L. Effects of humidity on tomato. Can. Agric. Eng. 1999, 41, 135-140.

79. Karim, M.F.; Hao, P.; Nordin, N.H.B.; Qiu, C.; Zeeshan, M.; Khan, A.A.; Shamsi, I.H. Effects of $\mathrm{CO}_{2}$ enrichment by fermentation of CRAM on growth, yield and physiological traits of cherry tomato. Saudi J. Biol. Sci. 2020, 27, 1041-1048. [CrossRef]

80. Kläring, H.P.; Hauschild, C.; Heißner, A.; Bar-Yosef, B. Model-based control of $\mathrm{CO}_{2}$ concentration in greenhouses at ambient levels increases cucumber yield. Agric. For. Meteorol. 2007, 143, 208-216. [CrossRef]

81. Song, H.; Li, Y.; Xu, X.; Zhang, J.; Zheng, S.; Hou, L.; Xing, G.; Li, M. Analysis of genes related to chlorophyll metabolism under elevated $\mathrm{CO}_{2}$ in cucumber (Cucumis sativus L.). Sci. Hortic. 2020, 261, 108988. [CrossRef]

82. Stanghellini, C.; Incrocci, L.; Gázquez, J.C.; Dimauro, B. Carbon dioxide concentration in Mediterranean greenhouses: How much lost production? Acta Hortic. 2008, 801, 1541-1549. [CrossRef]

83. Sánchez-Guerrero, M.C.; Lorenzo, P.; Medrano, E.; Baille, A.; Castilla, N. Effects of EC-based irrigation scheduling and CO 2 enrichment on water use efficiency of a greenhouse cucumber crop. Agric. Water Manag. 2009, 96, 429-436. [CrossRef]

84. Nelson, P.V. Greenhouse Operation and Management, 7th ed.; Prentice Hall: Upper Saddle River, NJ, USA, $2014 ;$ pp. $159-169$.

85. Yang, X.; Zhang, P.; Wei, Z.; Liu, J.; Hu, X.; Liu, F. Effects of $\mathrm{CO}_{2}$ fertilization on tomato fruit quality under reduced irrigation. Agric. Water Manag. 2020, 230, 105985. [CrossRef]

86. Zhang, S.; Guo, Y.; Zhao, H.; Wang, Y.; Chow, D.; Fang, Y. Methodologies of control strategies for improving energy efficiency in agricultural greenhouses. J. Clean. Prod. 2020, 274, 122695. [CrossRef]

87. Ikeda, T.; Ishigami, Y.; Goto, E. The effect of $\mathrm{CO}_{2}$ enrichment in a closed greenhouse equipped with NIR-reflecting film and EHP cooling on the yield and quality of tomato fruits during the summer season. J. Agric. Meteorol. 2020, 76, 104-110. [CrossRef]

88. Bartzanas, T.B.T.K.C.; Boulard, T.; Kittas, C. Effect of vent arrangement on windward ventilation of a tunnel greenhouse. Biosyst. Eng. 2004, 88, 479-490. [CrossRef]

89. Katsoulas, N.; Nikolaou, G.; Neocleous, D.; Kittas, C. Microclimate and cucumber crop transpiration in a greenhouse cooled by pad and fan system. Acta Hortic. 2020, 1271, 235-240. [CrossRef]

90. Katsoulas, N.; Savvas, D.; Kitta, E.; Bartzanas, T.; Kittas, C. Extension and evaluation of a model for automatic drainage solution management in tomato crops grown in semi-closed hydroponic systems. Comput. Electron. Agric. 2015, 113, 61-71. [CrossRef]

91. Thongbai, P.; Kozai, T.; Ohyama, K. $\mathrm{CO}_{2}$ and air circulation effects on photosynthesis and transpiration of tomato seedlings. Sci. Hortic. 2010, 126, 338-344. [CrossRef]

92. Elings, A.; De Visser, P.H.B.; Marcelis, L.F.M.; Heinen, M.; van Den Boogaard, H.A.G.M.; Gieling, T.H.; Werner, B.E. Feed-Forward Control of Water and Nutrient Supply in Greenhouse Horticulture: Development of a System. Acta Hortic. 2004, 654, 195-202. [CrossRef]

93. Ghoulem, M.; El Moueddeb, K.; Nehdi, E.; Zhong, F.; Calautit, J. Analysis of passive downdraught evaporative cooling windcatcher for greenhouses in hot climatic conditions: Parametric study and impact of neighbouring structures. Biosyst. Eng. 2020, 197, 105-121. [CrossRef]

94. Choab, N.; Allouhi, A.; El Maakoul, A.; Kousksou, T. Effect of Greenhouse Design Parameters on the Heating and Cooling Requirement of Greenhouses in Moroccan Climatic Conditions. IEEE Access 2020, 9, 2986-3003. [CrossRef]

95. Ghoulem, M.; El Moueddeb, K.; Nehdi, E.; Boukhanouf, R.; Calautit, J.K. Greenhouse design and cooling technologies for sustainable food cultivation in hot climates: Review of current practice and future status. Biosyst. Eng. 2019, 183, 121-150. [CrossRef]

96. Bartzanas, T.; Tchamitchian, M.; Kittas, C. Influence of the heating method on greenhouse microclimate and energy consumption. Biosyst. Eng. 2005, 91, 487-499. [CrossRef]

97. Gourdo, L.; Fatnassi, H.; Bouharroud, R.; Ezzaeri, K.; Bazgaou, A.; Wifaya, A.; Demrati, H.; Bekkaoui, A.; Aharoune, A.; Poncet, C.; et al. Heating canarian greenhouse with a passive solar water-sleeve system: Effect on microclimate and tomato crop yield. Sol. Energy 2019, 188, 1349-1359. [CrossRef] 
98. Rheinlaender, J. Fossil and Solar Heating of Greenhouses for Vegetable Production in Cyprus. Report on the 2nd Year of Activities of the ARI/GTZ Project at Athalassa (Nicosia); Agricultural Research Institute and German Agency for Technical Cooperation: Nicosia, Cyprus, 1983.

99. Rheinlaender, J. Conventional and Solar Heating of Greenhouses for Vegetable Production in Cyprus. Report on the Research Work of the ARI/ GTZ Project at Athalassa and Zyghi; Agricultural Research Institute and German Agency for Technical Cooperation: Nicosia, Cyprus, 1984.

100. Chahidi, L.O.; Fossa, M.; Priarone, A.; Mechaqrane, A. Energy saving strategies in sustainable greenhouse cultivation in the mediterranean climate-A case study. Appl. Energy 2021, 282, 116156. [CrossRef]

101. Bazgaou, A.; Fatnassi, H.; Bouharroud, R.; Ezzaeri, K.; Gourdo, L.; Wifaya, A.; Demrati, H.; Elame, F.; Carreño-Ortega, A.; Bekkaoui, A.; et al. Effect of active solar heating system on microclimate, development, yield and fruit quality in greenhouse tomato production. Renew. Energy 2021, 165, 237-250. [CrossRef]

102. Jia, H.; Wang, Z.; Zhang, J.; Li, W.; Ren, Z.; Jia, Z.; Wang, Q. Effects of biodegradable mulch on soil water and heat conditions, yield and quality of processing tomatoes by drip irrigation. J. Arid. Land 2020, 12, 819-836. [CrossRef] 